\title{
CHŪYA NAKAHARA JAKO TWÓRCA JAPOŃSKIEGO SONETU: PERSPEKTYWY PRZEKŁADU
}

\section{Wstęp}

W wydanej w 1992 r., jedynej jak dotąd na polskim rynku antologii współczesnej poezji japońskiej pt. Wiśnie rozkwitte pośród zimy liryka Chūyi Nakahary zajmuje bardzo marginalna pozycję. W zbiorze zamieszczono przekłady tylko czterech wierszy tego poety, w dodatku jakość przekładów raczej niewiele powie polskiemu czytelnikowi o tym, jak bardzo utalentowanym poetą był zmarly w wieku zaledwie 30 lat Nakahara.

Stanisław Barańczak w eseju Maty, lecz, maksymalistyczny manifest translatologiczny stwierdza: „Nie ma żadnego usprawiedliwienia dla powstania złego wiersza, jest zawsze lepiej, gdy go nie ma, niż gdy jest. Zła literatura to nie tylko, jakby powiedział tomista, nieobecność literatury dobrej; to raczej, jakby to z kolei ujął manichejczyk, aktywna obecność estetycznego Zła"1.

Celem artykułu jest ukazanie nowatorstwa Chūyi Nakahary na tle poezji japońskiej pierwszych dekad XX w. oraz zwrócenie uwagi na trudności, jakie musiał pokonać, aby zaadaptować do poezji japońskiej wiersz sylabiczny i sylabotoniczny, a także formę sonetu. Natomiast porównanie oryginału sonetu Nakahary Mata kon haru (Wiosna znów prayjdzie) z przekładem zamieszczonym w rzeczonej antologii ma udowodnić, że ten poeta zasługuje na lepsze tłumaczenia i dogłębne zbadanie jego twórczości, co pozwoliłoby przybliżyć go polskiemu czytelnikowi ${ }^{2}$ Zgodnie z teza Anny Bednarczyk na temat mnogości dominant w przekładzie ${ }^{3} \mathrm{w}$ niniejszym artykule zamierzam przedstawić perspektywę badawczą, która być może pozwoli rzucić więcej światła na twórczość tego prawie nieznanego w Polsce japońskiego poety.

ORCID: 0000-0002-4912-8342, DOI: 10.4467/23538724GS.20.058.13498

1 Por. S. Barańczak, Ocalone w tłumaczৃeniu. Sžkice o warsżtacie tłumacza poezji z dodatkiem Matej antologii przekłładón-problemów, Kraków 2004, s. 34.

2 W końcowej części artykułu zamieszczam własną propozycję tłumaczenia omawianego sonetu, kierując się myślą Paula Ricoeura, że: ,jedyną metodą krytyki jakiegoś przekładu (...) jest zaproponowanie innej wersji, co do której zakładamy, przypuszczamy, że jest lepsza lub odmienna"; cyt. za: Wspótczesne teorie przekładu. Antologia, red. M. Heydel, P. Bukowski, Kraków 2009, s. 357.

3 Por. A. Bednarczyk, W poszukiwaniu dominanty translatorskiej, Warszawa 2008, s. 15. 


\section{Życie i twórczość Chūyi Nakahary (1907-1937) na tle epoki}

W początkowych dwóch, trzech dekadach po restauracji Meiji (1868) w poezji japońskiej nadal panowały konwencje obowiązujące w liryce okresu klasycznego - poeci aktywni w ostatnich latach XIX w. starali się tworzyć przede wszystkim tzw. krótkie pieśni (tanka) zgodnie z obowiązującym metrum 5 wersów liczących naprzemiennie: $5-7-5-7-7$ mor (tanka liczyła więc łącznie 31 mor). Pierwszym zwiastunem powstania formy nowego nowożytnego wiersza (nazywanego już potem mianem shi, po prostu 'wiersz') było opublikowanie w roku 1882 antologii przekładów głównie z poetów angielskich i amerykańskich pt. Shintaishishō (Wybór nonych wiersyy $)^{4}$. Kolejną antologia przekładów był opublikowany w 1889 r. przez Ōgai’a Moriego (1862-1922) - rok po jego powrocie ze stypendium w Niemczech - zbiór wierszy głównie poetów niemieckich i angielskich (tych drugich poprzez przekłady niemieckie) - Omokage (Ślady) ${ }^{5}$.

W 1899 r. nauczyciel szkolny i poeta Hiroshi Yosano (1873-1935), działający pod pseudonimem artystycznym Tekkan, założył Shinshisha (Nowe Towarzystwo Poetyckie), które zaczęło wydawać pismo literackie Myōjō (Jutrzenkea), stawiające sobie za zadanie promowanie nowych form wiersza japońskiego. Jednak największym odkryciem literackim w grupie Tekkana okazała się jego żona, Akiko Yosano (1878-1942), która zadebiutowała w 1900 r. tomikiem krótkich wierszy tanka, zatytułowanym Midaregami (W tosy w nieładzie). W zakresie metrum to niewatpliwie były nadal tanki, ale przecież inne - Akiko Yosano łamała wszelkie konwenanse, tradycyjną moralność, zrywała z klasyczną poetyką. Pisała liryki przepojone erotyzmem, uwielbieniem piękna kobiecego ciała, używała modnego wówczas słownictwa pełnego zapożyczeń ${ }^{6}$.

Na zakończenie tej wybiórczej prezentacji dokonań poetyckich w epoce, w której debiutował Chūya Nakahara, nie sposób nie wspomnieć jeszcze o dwóch ważnych wydarzeniach. Pierwszym z nich było wydanie w 1905 r. przez Bina Uedę (1874-1916) antologii przekładów pt. Kaichooon (Odgłos prazyplywn). W przeciwieństwie do poprzednich tłumaczy, którzy skupiali się głównie na poezji angielskiej,

4 Wiele z tłumaczeń zamieszczonych w tej antologii zyskało uznanie krytyków, czytelników i weszło do kanonu na dziesiątki lat - dość wspomnieć choćby o kongenialnym tłumaczeniu Elegy Written in a Country Churchyard Thomasa Graya pióra Ryōkichiego Yatabe (1851-1899); por. The Cambridge history of Japanese literature, eds. H. Shirane, T. Suzuki, D.B. Lurie, Cambridge 2016, s. 613.

5 Mori idzie o krok dalej w porównaniu do redaktorów Shintaishishō i np. w przekładzie Mignons Gesang Goethego (tytuł japoński: Minyon no uta) proponuje tłumaczyć na japoński jeden wers niemieckiego oryginału (również zbudowany na pentametrze jambicznym) za pomoca jednego wersu 20-morowego, ze średniówką w połowie; por. W. Ko, The Symbolists' Influence on Japanese Poetry, „Comparative Literature Studies” 1971, no. 8 (3), s. 254-265, https://www.jstor.org/stable/40467962 (dostęp: 3.01.2021).

6 The Cambridge history..., s. 618. 
amerykańskiej czy niemieckiej, Ueda uwzględnił przede wszystkim utwory poetów francuskich i belgijskich, kładąc duży nacisk na parnasistów i symbolistów. Dzięki jego antologii przekładów japoński czytelnik po raz pierwszy miał okazję zetknąć się z poezją Verlaine’a, Baudelaire'a, Rimbauda, Mallarmégo czy Verhaerena ${ }^{7}$.

Drugim z wydarzeń - szczególnie ważnym dla dalszego rozwoju artystycznego samego Nakahary - było wydanie w 1923 r. przez Shinkichiego Takahashiego (1901-1987) tomiku wierszy Dadaisuto Shinkichi no shi (Wiersze dadaisty Shinkichiego). W takiej właśnie epoce burzliwego fermentu artystycznego, ścierania się dawnej poezji waka z odważnymi próbami eksperymentowania rozwijał się talent poetycki Chūyi Nakahary.

Poeta urodził się w 1907 r. w prefekturze Yamaguchi, w rodzinie lekarza wojskowego. W wieku nastoletnim ojciec umieścił go w gimnazjum Ritsumeikan w Kioto. Przebywając w Kioto, Nakahara poznał początkującego wtedy poetę Tarō Tominagę (1901-1925) oraz przyszłego krytyka literackiego Hideo Kobayashiego (1902$1983)^{8}$. W tamtym czasie Nakahara zetknął się również z Shinkichim Takahashim, uznanym już poeta. Przeżył szok, dając się porwać nowemu prądowi. Próbował sił w dadaistycznych aforyzmach.

W 1925 r. zaczął się tokijski epizod w życiu Nakahary, najbardziej płodny artystycznie, ale też najbardziej wyniszczający młodego poetę. Podjął naukę w szkole przygotowawczej przy prywatnym Uniwersytecie Japońskim, szybko ją jednak porzucił i zaczął uczęszczać na kurs francuskiego do Athénée Français?.

W 1926 r. powstał jeden z najbardziej znanych wierszy Nakahary - Asa no uta (Piosenka poranna), na ówczesnym etapie poeta był juź świadomy swojej drogi twórczej. Chciał pisać sonety, ale czerpiąc również z bogactwa słownictwa klasycznego. Dużo eksperymentował, jednak nie spotkało się to z uznaniem ówczesnego świata literackiego. To właśnie w tamtych początkowych latach tokijskich na młodego poetę, bywalca ówczesnych herbaciarni i palarni opium, zwrócił uwagę muzyk modnej wtedy grupy Suruya - Saburō Moroi (1903-1977). Moroi zaproponował Nakaharze, że będzie podkładał muzykę do jego sonetów i tak do repertuaru grupy Suruya trafiły m.in. Asa no uta (Piosenka poranna), Kikyō (Powrót na wieś) czy inne utwory Nakahary ${ }^{10}$. W 1929 r. wraz z poznanymi w Tokio przyjaciółmi - Tetsutarō Kawakamim (1902-

7 Ueda był świetnym poetą i tłumaczem, a Kaichōon uważa się powszechnie za najwybitniejsze dokonanie w dziedzinie przekładu poezji I połowy XX w., wśród najwspanialszych utworów wymieniając takie wiersze, jak np. Rakuyō (Opadajace liście) - tłumaczenie Chanson d'automne Verlaine'a - ibidem, s. 619.

8 Przyjaźń z Kobayashim będzie trwała do końca życia Nakahary, co więcej, umierający w Kamakurze w 1937 r. poeta przekaże przyjacielowi pieczę nad jego spuścizną literacka.

${ }^{9}$ Należy zauważyć, że Chūya Nakahara przyjechał w 1925 r. do Tokio wciąż jeszcze zrujnowanego po wielkim trzęsieniu Kantō (1.09.1923), jednym z najstraszniejszych w skutkach kataklizmów w nowożytnej historii Japonii.

${ }_{10}$ Niewątpliwie przysporzyło to Nakaharze pewnej popularności, czyniąc z niego na swój sposób ulubieńca tokijskiej bohemy. 
1980) i Shōhei'em Ōoką (1909-1988) - Nahara zaczął wydawać pisemko Hakuchigun („Banda Głupców”), w którym nareszcie udało mu się opublikować wiele swoich utworów ${ }^{11}$. W 1933 r. Chūya Nakahara wydał w oficynie Kasama Shobō (w edycji dwujęzycznej: francusko-japońskiej) swój tomik przekładów poezji Artura Rimbau$\mathrm{da}^{12}$, a rok później wreszcie swój debiutancki tomik liryków - Yagi no uta (Pieśni kozła) ${ }^{13}$. W 1936 r. starszy syn poety zmarł na gruźlicę. Po tym ciosie poeta załamał się i do końca życia już nie odzyskał równowagi psychicznej. Niedługo potem, 23 października 1937 r. Chūya Nakahara zmarł w Kamakurze na zapalenie opon mózgowych.

Rok później, w 1938 r., Hideo Kobayashi, któremu Nakahara na łożu śmierci powierzył swoją spuściznę, wydał pośmiertnie drugi tomik jego poezji - Arishi bi no uta (Pieśni z tamtych dni) ${ }^{14}$. Nakahara jest przykładem zmarłego przedwcześnie, świetnie zapowiadającego się poety, którego sława rozbłysła po śmierci. Pozostawił po sobie około 350 wierszy (poza 2 opublikowanymi zbiorami, większość w rękopisach), wspomnienia i listy.

Nakahara jest poetą całkowicie nieznanym polskiemu czytelnikowi. Mimo dużej popularności i rozpoznawalności w Japonii do tej pory nie ukazał się po polsku żaden wybór jego wierszy, z wyjątkiem liryków zamieszczonych w antologii Wiśnie rozkwitte pośród zimy ${ }^{15}$.

\section{Trudności w adaptacji formy sonetu na gruncie japońskim}

Na czym polegały trudności z adaptacją w poezji japońskiej wiersza sylabicznego czy sylabotonicznego (zwłaszcza sonetu) i do jakiego stopnia musiał eksperymentować Nakahara, łamiąc dotychczasowe konwencje, aby te cele osiagnąć? Jak już wspomniałem, do początków minionego stulecia w Japonii panowała konwencja klasycznej poezji waka z charakterystycznym dla niej metrum krótkiego wiersza (tanki) o 5 wersach liczących naprzemiennie $5-7-5-7-7$ mor $^{16}$. Co do rymów,

11 Pismo to było wydawane zaledwie przez rok, ukazało się sześć numerów; por. M. Ueda, Konsaisu nihon jinmei jiten, Tokyo 2004, s. 962.

12 Zob. Ch. Nakahara, Futsuwa taishō Ranbō shishū: Jan Nikora Aruchüru Ranbō [Wybór wierszy Rimbauda - wydanie francusko-japońskie: Jean Nicolas Arthur Rimbaud], Tokyo 2020.

13 Po debiucie Nakahary ukazały się w prasie entuzjastyczne recenzje na temat jego twórczości, co otworzyło mu drogę do publikacji w renomowanych periodykach - Shiki („Czterech Porach Roku”) i w Bungakukai („Świecie Literatury”).

14 To właśnie Kobayashi i Ōoka dołożyli starań, by już po wojnie, w latach 1967-1971 wydać dzieła wszystkie poety, zebrane w pięciu tomach.

15 Kilka wierszy Ch. Nakahary przetłumaczyła swego czasu Agnieszka Żuławska-Umeda zob. A. Żuławska-Umeda (tłum.), Wiersze / Chìya Nakahara, „Japonica” 1993, z. 1, s. 81-86.

16 O tym, że w odniesieniu do japońskiego, zamiast mówić o sylabach, większy sens ma odwołanie się do mory jako jednostki miary wiersza, wspomniano już powyżej; por. R. Huszcza, M. Ikushima, J. Majewski, Gramatyka japonska. Podrecznik z.́miczeniami, t. 1, Warszawa 1988, s. 116-117. 
sytuacja jest o tyle skomplikowana, że w języku japońskim ze względu na składnię typu SOV, brak deklinacji nominalnych kategorii oraz dość sztywny szyk zdania oraz fakt, że prawie wszystkie sylaby są otwarte, a jednocześnie jest to język o dość małej liczbie samogłosek (zaledwie 5), bardzo trudno uzyskać jakiekolwiek rymy, w zasadzie jest to zadanie karkołomne. W historii rozwoju japońskiej poezji wyjątkowo rzadkie były takie przypadki - jednym z twórców był bez wątpienia Nakahara, wcześniej podobne wysiłki poczynił Ōgai Mori w antologii przekładów Kaichōon. Próby tworzenia poezji rymowanej, a nawet rezultaty osiagnięte przez Nakaharę w jego lirykach nie zawsze można uznać za satysfakcjonujące.

Pozostaje jeszcze kwestia odmienności typologicznej akcentu japońskiego od akcentu charakterystycznego dla większości języków europejskich. W takich językach, jak polski czy angielski, mamy do czynienia z akcentem ekspiracyjnym, natomiast w języku japońskim jest to akcent melodyczny, tonalny ${ }^{17}$. Jest on przy tym dość skomplikowany ${ }^{18}$, nie ma stałej pozycji w zdaniu, dla poszczególnych części mowy istnieje po kilka wzorców akcentuacji. Dodatkowo, akcent japoński jest zjawiskiem suprasegmentalnym, pod wpływem dołączania partykuł lub innych sufiksów jego miejsce może się przesuwać, jest to więc akcent swobodny, ruchomy.

Można zaryzykować hipotezę, że w sytuacji prawie niemożności uzyskania rymów, jak również kiedy odmienny charakter japońskiego akcentu nie pozwalał na stały układ stóp w wierszu, to właśnie regularnie powtarzające się wzorce kadencji stanowiły (zwłaszcza dla poety obdarzonego takim słuchem muzycznym jak Chūya Nakahara) namiastkę (czy wręcz jedyny realny odpowiednik) stóp europejskiego wiersza sylabotonicznego ${ }^{19}$.

\section{Analiza sonetu Mata kon haru (Wiosna znów prayjdzie) ${ }^{20}$}

Utwór ten pochodzi z ostatniego okresu twórczości Chūyi Nakahary, możemy nawet precyzyjniej umiejscowić datę napisania tego liryku w ostatnim roku życia poety, bowiem pobrzmiewa w nim tragizm utraty starszego syna, Fumiyi, który zmarł

17 Por. Encyklopedia jesyykoznawstwa ogólnego, red. M. Jurkowski, Wrocław 1995, s. 22; R. Huszcza, M. Ikushima, J. Majewski, Gramatyka japońska..., s. 116.

18 Wyróżnia się dwa tony - wysoki i niski oraz ton pośredni, neutralny, przy czym dystynktywny jest wyłącznie spadek tonu, nie jego podniesienie; por. R. Huszcza, M. Ikushima, J. Majewski, Gramatyka japońska..., s. 117.

19 Por. Shinchō Nihon bungaku shöjiten [Mała encyklopedia literatury japońskiej wydawnictwa Shinchōsha], eds. S. Itō, Y. Kawabata, Tokyo 1968, s. 853, gdzie wyraźnie użyto sformułowania, że Nakahara układał sonety.

20 Transkrypcja oryginału: Mata kon haru to bito wa iu / Shikashi watashi wa tsurai no da / Haru ga kitatte nan ni naro / Ano ko ga kaette kuru njanai / Omoeba kotoshi no gogatsu ni wa / Omae o idaite dōbutsuen / Zōo misetemo nya to ii / Tori o misetemo nya datta. / Saigo ni miseta shika dake wa / Kado ni yoppodo bikarete ka / Nan to mo iwazu nagameteta. / Hon ni omae mo ano toki wa / Kono yo no bikari 
w 1936 r. W komponowaniu wierszy poeta szukał ukojenia, były one próba poradzenia sobie z tym, co niewyrażalne, nie do pojęcia.

W warstwie semantycznej analizowany utwór ukazuje bezmiar bólu podmiotu lirycznego, który stracił sens życia - haru ga kitatte nan ni naro, ano ko ga kaette kuru njanai (na có̀̇ mi wiosna, niechby nawet prąysz̧ła? Moje dziecko już do mnie nie wróci). Następnie sonet płynnie przechodzi w epitafium dla zmarłego Fumiyi - podmiot liryczny przypomina sobie rodzinną wizyte w ogrodzie zoologicznym i niemy zachwyt małego chłopca rozłożystym porożem jelenia. Ojciec-poeta zbiera tutaj chwile szczęścia, drogocenne wspomnienia, które niczym klejnoty umieszcza w szkatułkach pamięci po to, by w ostatnim wersie stwierdzić, że syn był dla niego całym światem.

W warstwie językowej zwracają uwage liczne kolokwializmy użyte przez poetę, np. w trzecim wersie: haru ga kitatte nan ni naro, czy w ostatnim: tatte nagamete itakke ga. Ta cecha odróżnia powyższy sonet od wierszy pochodzących z wczesnych lat twórczości poety ${ }^{21}$. Jeśli chodzi o inne środki językowe, jakimi się posłużył, należy przede wszystkim zwrócić uwagę na pierwszy wers: Mata kon haru to bito wa iu, gdzie dla zachowania melodyjności frazy mamy świetnie użytą inwersję (w potocznym ówczesnym japońskim to zdanie mogłoby brzmieć: Mata haru ga komu to bito wa $i u{ }^{22}$. Dzięki temu zabiegowi stylistycznemu poecie udało się zachować średniówkę po 7. morze. Widać pewne paralelizmy składniowe w budowie pierwszych wersów trzech ostatnich strof (każdy z nich kończy się na temacie) ${ }^{23}$. Co więcej, w pierwszych dwóch wersach drugiej strofy mamy do czynienia z instrumentacja głoskową - obydwa wersy zaczynają się od bardzo podobnych słów: omoeba (gdy wspomne) w pierwszym wersie i omae o (ciebie) w drugim. Do tego dochodzi jeszcze paralelizm składniowy w kolejnych dwóch wersach drugiej strofy.

Analizowany sonet składa się z czterech strof - dwie pierwsze sa 4-wersowe, po czym następują dwie strofy 3-wersowe. Cały utwór napisany jest regularnym wierszem 12-morowym (niektóre wersy są 13-morowe, ale Nakahara trochę nonszalancko poczynał sobie z wymogiem stałej liczby mor w wersach, bardziej opierał się na sylabizmie - zupełnie nie narusza to jednak melodyjności tego sonetu).

no tada naka ni / Tatte nagamete itakke ga; por. K. Adachi, W. Kotański, T. Śliwiak, Wiśnie rozkwitte pośród zimy. Antologia wspótczesnej poezji japońskiej, Tokio 1992, s. 318.

${ }^{21}$ Jak podaja biografowie twórczości Nakahary, w początkowych latach poeta skłaniał się ku językowi klasycznemu, choć w nowatorskiej formie wiersza sylabicznego czy nawet sonetu. Przykład liryku Wiosna zৃów prayjdzie pokazuje, że w ostatniej fazie twórczości, zwłaszcza gdy przeżywał rozpacz po stracie syna, Chūya Nakahara sięgnął po kolokwialny język, nadal jednak nie rezygnując z formy sonetu, nie poświęcając melodyjności wiersza; zob. M. Sasaki, Nakahara Chüya - chinmoku no ongaku [Nakahara Chūya - muzyka ciszy], Tokyo 2017.

${ }^{22}$ Forma komu to dawny hortativus, odpowiadający dzisiejszej formie: kuru deshō (tryb przypuszczający, odnoszący się do zdarzeń, które dopiero mają nadejść). Można by dać dosłowne tłumaczenie: wiosna chyba prayjdzie.

$23 \mathrm{~W}$ poetyce haiku i tanki takie kończenie wersów na partykułach dopełniających metrum nazywano kireji. 
Aby udowodnić melodyjność wiersza Nakahary, wykorzystałem ogólnodostępny japoński syntezator mowy, czyli projekt OJAD (Online Japanese Accent Dictionary) ${ }^{24}$. Skoro w japońskim akcencie dystynktywna jest kadencja tonu, to prześledzenie wykresu tonalnego pozwoli odpowiedzieć na pytanie o istotę melodyjności liryków Nakahary (rys. 1). Prześledźmy rozłożenie akcentów na przykładzie pierwszej strofy sonetu:

Mata kon haru to hito wa iu

Shikashi watashi wa tsurai no da

Haru ga kitatte nan ni naro

Ano ko ga kaette ruru janai.

Sylaby akcentowane, czyli te, na których następuje kadencja tonu, zaznaczono podkreśleniem ${ }^{25}$. Łatwo daje się zauważyć występowanie w pierwszym i czwartym wersie na początku długich zestrojów akcentowych (akcenty w tych wersach padaja na 5. i 9. morze), z kolei w drugim i trzecim wersie akcent pada prawie na samym początku wersu i potem dopiero pod koniec (w drugim wersie na 2. i 9. morze, w trzecim na 1., 4. i 8. morze $)^{26}$. Czyż nie można przyrównać tych powtarzających się rozkładów akcentów w wersach do stałych stóp w wierszu europejskim lub układu rymów (których uzyskanie jest w japońskim prawie niewykonalne)? Per analogiam, można by więc stwierdzić, że sonet Wiosna znów prayjjdzie Nakahary cechuje się układem „rymów”: $a-b-b-a / a-a-b-b / a-a-a / a-b-a^{27}$.

24 Syntezator mowy, czyli właściwie Prosody Tutor Suzuki-kun, jest tylko jedna z funkcjonalności portalu OJAD. Przede wszystkim jest to największy jak dotychczas słownik ortofoniczny języka japońskiego wraz z pomocami do nauki prawidłowej wymowy i intonacji. Jedną z funkcjonalności jest możliwość uzyskania wykresu tonalnego dla wklejonego tekstu po japońsku, jak również za pomocą syntezatora mowy można uzyskać zapis dźwiękowy tego tekstu; por. N. Minematsu, OJAD. Online Japanese Accent Dictionary, http://www.gavo.t.u-tokyo.ac.jp/ojad/ (dostęp: 3.01.2021). Na wartość glottodydaktyczną syntezatora mowy wskazywano już w licznych pracach; zob. też: N. Minematsu et al., OJAD: a Free Online Accent and Intonation Dictionary for Teachers and Learners of Japanese, „Proc. SLaTE” 2013, s. 94, http://www.gavo.t.u-tokyo.ac.jp/ mine/paper/PDF/2013/SLATE_p94_t2013-8.pdf (dostęp: 3.01.2021).

${ }_{25}$ Trzeba tutaj jednak stanowczo podkreślić, że język japoński daje - w porównaniu np. z polszczyzną - bardzo zubożone możliwości kształtowania tkanki wiersza i zmieniania układu stóp, miejsc akcentu. Dzieje się tak z uwagi, po pierwsze, na znaczną sztywność szyku zdania japońskiego, z niewielkim marginesem inwersji, po drugie dlatego, że akcent japoński (jak wyjaśniono powyżej, o całkowicie odmiennym charakterze niż akcent polski) nie jest stały - jest swobodny ruchomy; por. R. Huszcza, M. Ikushima, J. Majewski, Gramatyka japońska..., s. 116.

26 Trzeci wers trochę zaburza obraz, lecz nie wydaje się to niczym niezwykłym przy omawianych powyżej trudnościach, na jakie naraża poetę specyfika akcentu japońskiego - jedynie wybitnemu słuchowi muzycznemu Nakahary zawdzięczamy to, że aż do takiego stopnia udało mu się zorganizować tkankę wiersza.

${ }^{27}$ Klasyczny sonet petrarkowski to wiersz składający się z 2 tetrastychów i 2 tercyn z rymami okalającymi w tetrastychach i tercynami rymowanymi podwójnie lub potrójnie; por. Stownik terminów literackich, red. M. Głowiński, Wrocław 1988, s. 475-476. Oczywiście, nie można stawiać 


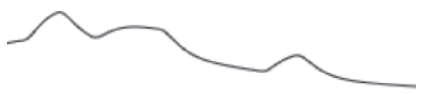

またこんはるとひとはいう

またこん春と人は云う

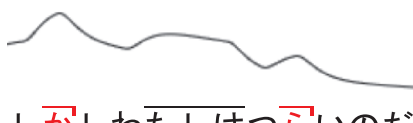

しかしわたしはっらいのだ

しかし私は辛いのだ

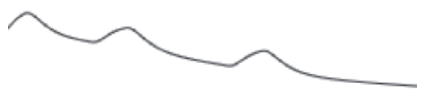

はるがきたってなんになる

春が来たって何になろ

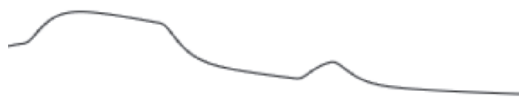

あのこがかえってくるんじゃない

あの子が返って来るんじゃない

1 strofa

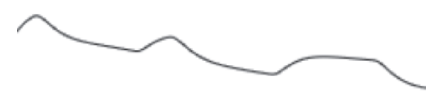

さいごにみせたしかだけは

最後に見せた鹿だけは

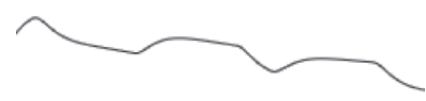

かどにようぽどひかれてか

角によっぽど惹かれてか

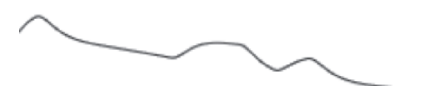

なんともいわずながめてた

何とも云わず眺めてた

3 strofa

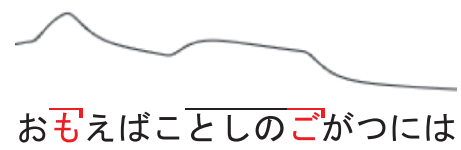

おもえば今年の五月には

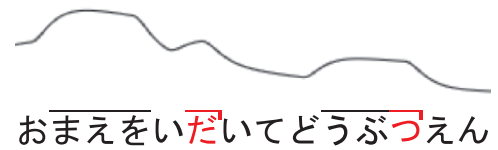

おまえを抱いて動物園

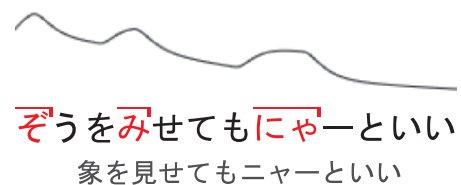

象を見せてもニャーといい

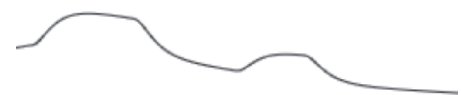

とりをみせてもにゃ一だった

鳥を見せてもニャーだった

2 strofa

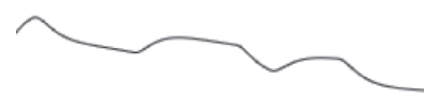

ほんにおまえもあのときは

ほんにおまえもあの時は

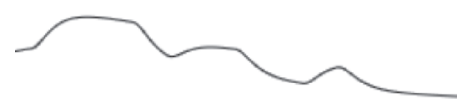

このよのひかりのただなかに 此の世の光のただ中に

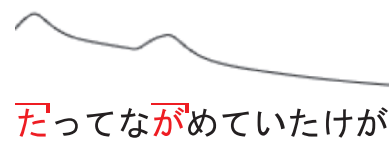

立って眺めていたっけが

4 strofa

Rys. 1. Wykres tonalny dla sonetu Mata kon haru (Wiosna znów prayjdzie)

Źródło: Wykresy sporządzono za pomocą serwisu: Prosody Tutor Suzuki-kun stanowiącego integralną część portalu OJAD; zob. N. Minematsu, OJAD. Online Japanese Accent Dictionary, http://www. gavo.t.u-tokyo.ac.jp/ojad/ (dostęp: 3.01.2021). 


\section{Antologia Wiśnie rozkwitte pośród zimy}

Wybór współczesnej poezji japońskiej pt. Wiśnie rozkwitte pośród zimy został wydany w Tokio przez wydawnictwo Kokusai Bunka Shuppansha w 1992 r. ${ }^{28}$ Bez watpienia powstanie tego tomiku możemy zawdzięczać zaangażowaniu Kazuko Adachi, polonistki mającej w swoim dorobku kilka przekładów z literatury polskiej na japoński, oraz tłumacza prof. Wiesława Kotańskiego (1915-2005), jak również krakowskiego poety Tadeusza Śliwiaka (1928-1994), który wziął na siebie rolę redaktora tłumaczeń Kotańskiego.

Mamy tutaj do czynienia z dość specyficzną antologia poezji, na której kształt wpłynęły zarówno konkretne preferencje Kazuko Adachi, w całości odpowiedzialnej za wybór twórców i ich wierszy, jak i określona strategia translatorska przyjęta przez pozostałych dwóch współtwórców tego zbioru ${ }^{29}$. Antologia zawiera około 200 utworów autorstwa 130 poetów i obejmuje prawie 100 lat rozwoju współczesnej poezji japońskiej. Na pytanie o jej reprezentatywność nie jest łatwo udzielić odpowiedzi. Niewątpliwie pierwsza redaktorka antologii, Adachi, zadbała - zgodnie z posiadaną wiedzą - o dobór najbardziej reprezentatywnych poetów i ich najszerzej znanych, popularnych wierszy. Rzeczywiście, jeśli prześledzimy rozwój poezji japońskiej w epokach Meiji, Taishō i Shōwa, to w Wiśniach... udało się redaktorom zamieścić wiele słynnych utworów, które zmieniły oblicze nowożytnego wiersza japońskiego, wyznaczały nowe trendy.

Od wydania Wiśni... w 1992 r. mija 28 lat. W tym czasie nie ukazała się w języku polskim żadna antologia współczesnej poezji japońskiej. Nie ma też zbyt wielu prac krytycznych, co pokazuje, że w dziedzinie przekładów japońskiej poezji i krytyki tychże pozostaje jeszcze bardzo dużo do zrobienia.

\footnotetext{
znaku równości pomiędzy stopami wiersza europejskiego a objaśnionymi powyżej sposobami takiej organizacji tkanki wiersza japońskiego, by uzyskać efekt w miarę stałych miejsc padania akcentu tonalnego, ale wydaje się, że były to jedyne dostępne japońskim poetom symbolistom środki pozwalające na adaptację na grunt japoński wiersza sylabotonicznego czy formy sonetu, o czym Nakahara zapewne doskonale wiedział.

${ }^{28}$ Japoński tytuł antologii pochodzi od tytułu wiersza poetki Kazue Shinkawy, którego przekład również został zamieszczony w tym zbiorze; por. K. Adachi, W. Kotański, T. Śliwiak, Wiśnie rozkwitte..., s. 487.

${ }^{29}$ O swoich preferencjach K. Adachi pisze w posłowiu do Wiśni.... „Starałam się wybierać reprezentatywne dzieła poetyckie, biorąc pod uwagę tych twórców, którzy rośli w sławę od średniej fazy okresu Meiji aż po żyjących aktualnie pięćdziesięciolatków, przy czym utwory owych poetów musiały - według zasad tej selekcji - być napisane współczesnym językiem mówionym z pominięciem frazeologii klasycznej i mieć formę wiersza wolnego, różną od stylu japońskiej poezji starożytnej i wolną od konwencji sylabizmu. Ponadto selekcjonowałam również te wiersze pod względem możliwości ich przekładu na język polski”; ibidem, s. 564.
} 
Przejdźmy do porównania oryginału wiersza Nakahary z przekładem na polski, zamieszczonym w antologii Wisnie rozkwitte pośród zimy $y^{30}$.

O ile w warstwie semantycznej niewiele można polskiemu przekładowi zarzucić, o tyle momentami dobór słownictwa powoduje, że przekład staje się mało wyrazisty. Wystarczy porównać pierwszą strofę:

a) oryginal:
Mata kon haru to bito wa in
Shikashi watashi wa tsurai no da
Haru ga kitatte nan ni naro
Ano ko ga kaette kuru janai

\section{b) tłumaczenie}

$$
\begin{aligned}
& \text { Mówi się, że wiosna pojawi się po raz drugi, } \\
& \text { Mnie jednak ciężko jest na duszy. } \\
& \text { Choćby i nadeszła wiosna, po co mi ona, } \\
& \text { Skoro moje zmarłe dziecko już nie powróci? }
\end{aligned}
$$

Zwraca tutaj uwagę sztuczność pierwszego wersu, jego zupełnie suchy, pozbawiony wyrazu wydźwięk ${ }^{31}$. Niepotrzebne wydaje się powtórzenie słowa wiosna w obrębie jednej strofy - język japoński uwielbia powtórzenia, polski przeciwnie, jest to uważane za usterkę stylistyczna - tutaj znowu raczej widać zbyt sztywne trzymanie się przez tłumaczy oryginału i zakusy, by tłumaczyć dosłownie ${ }^{32}$. Razi również pleonazm w ostatnim wersie: moje zmarte dziecko już nie powróci33.

Podobnego rodzaju usterki można dostrzec w całym tekście przekładu, jednakże największym błędem tego tłumaczenia wydaje się fakt, że sonet Chūyi Nakahary został przełożony wierszem wolnym. Tłumacze nie pokusili się o zastosowanie wiersza sylabicznego (co z taka gracją czynił sam Nakahara), jakby nie dopatrzyli się w oryginale formy sonetu. Jest to tym bardziej dziwne, jeśli wziać pod uwagę, że ostatni z tłumaczy-redaktorów, Tadeusz Śliwiak, był poetą, twórcą piosenek i taka forma wiersza nie powinna być dla niego niczym obcym. Można powiedzieć, że

30 Tłumaczenie zawarte $\mathrm{w}$ antologii Wiśnie rozkwitte pośród zimy: „Mówi się, że wiosna pojawi się po raz drugi, / Mnie jednak ciężko jest na duszy. / Choćby i nadeszła wiosna, po co mi ona, / skoro moje zmarłe dziecko już nie powróci? / Przypominam sobie, jak w maju w tym roku, / niosłem cię na ręku w ogrodzie zoologicznym, / Mówiłeś „miau”, gdy pokazałem ci słonia, / mówiłeś też „miau”, gdy pokazałem ci ptaka. / Jedynie na jelenia, którego ci pokazałem na końcu, / może dlatego, że byłeś wręcz oczarowany jego rogami, / patrzyłeś, niczego nie mówiąc. / Doprawdy, tyś także w tamtych chwilach / stał w samym centrum naszego świata / i oglądałeś go w zachwycie..."; por. ibidem, s. 319 .

31 Wraz z zupełnie nieadekwatnym sformułowaniem po raz, drugi-wiosna wszak to nie efemeryda, była już dziesiątki razy w życiu podmiotu lirycznego, który jednakże stracił nadzieję na to, że żnown przyjdzie. Po japońsku jest tam zwyczajna fraza: powiadaja że żów nadejdzie wiosna.

${ }^{32}$ Do podobnych powtórzeń uciekli się redaktorzy również w dwóch ostatnich wersach drugiej strofy i pierwszym wersie strofy trzeciej, gdzie w bliskim sąsiedztwie trzy razy występuje forma czasownika pokazałem. Zarówno stylistyka języka japońskiego (w przeciwieństwie do polszczyzny), jak i poetyka klasycznego wiersza waka wartościowały pozytywnie powtórzenia fraz, nawet znajdujących się blisko siebie.

33 Po japońsku jest tam zwyczajna fraza: (to - które wspominam) dziecko już nie powróci. 
w ten sposób wysiłek Chūyi Nakahary został bezpowrotnie zmarnowany, a polski czytelnik otrzymał suchy, beznamiętny wiersz, na podstawie którego nie jest w stanie wyrobić sobie żadnego zdania o tym niezwykle uzdolnionym i uwielbianym w Japonii poecie.

Posługując się terminologia zaproponowana przez Antoine’a Bermana na temat tendencji deformujących przekład ${ }^{34}$, można stwierdzić, że tłumaczenie analizowanego sonetu Nakahary zawarte w antologii Wiśnie rozkwitte pośród zimy jest zracjonalizowane, objaśniające, niby uszlachetniające język, ale de facto zubożające go jakościowo. Przede wszystkim zaś zniszczony został rytm tej poezji.

\section{Propozycja tłumaczenia sonetu Chūyi Nakahary Wiosna znów prąyjdzie}

W świetle powyższych analiz nie ulega wattpliwości, że dominantą estetyczną tego utworu jest jego układ metryczny. Właśnie takie wyzwanie stawia liryk Nakahary przed tłumaczem - tłumaczenie musi mieć formę sonetu.

Moja propozycja zachowuje klasyczną formę sonetu: dwa pierwsze tetrastychy maja rymy okalające: $a-b-b-a$, zaś dwie ostatnie tercyny rymują się podwójnie: $c-d-c / d-c-d$. Wszystkie rymy są żeńskie, zupełne. Każdy wers jest 11-zgłoskowym tetrametrem, zbudowanym na układzie stóp: trochej - amfibrach // trochej - peon trzeci, ze średniówką po piątej sylabie (z pewnymi, drobnymi rozbieżnościami w układzie stóp w czterech wersach - co jednak nie zaburzyło melodyjności przekładu).

Chūya Nakahara, Wiosna znów prayjdzie

Wiosna znów przyjdzie, ludzie powiadali, Jednak ma dusza dzisiaj umęczona.

Niechby i przyszła, na cóż że mi ona?

Dziecko odeszło, nic go nie ocali.

Wspomnę dziś zoo, klatki, gdzieśmy stali

W maju. Twa buzia do mej przytulona.

- Miau - powiedziałeś, gdy wskazałem słonia.

- Miau - też wołałeś, ptaki widząc w dali.

Lecz urzeczony widokiem jelenia,

Jego pięknymi, wielkimi rogami,

Stałeś milczący, w pełni zadziwienia.

34 Zob. A. Berman, Pręektad jako dośniadczenie obcego; cyt. za: Wspótczesne teorie..., s. 253 i nn. 
Tyś odszedł, ja zaś biję się z myślami.

Byłeś mi całym światem bez wattpienia.

Będę miał ciebie zawsze przed oczami.

Należy zadać sobie pytanie o koszty takiej właśnie organizacji tkanki wiersza, czyli o straty w porównaniu z oryginałem. Skrupulatny krytyk zauważy zapewne na płaszczyźnie semantycznej drobne odstępstwa od oryginału w ostatnim wersie pierwszej strofy (po jap. dosł.: džiecko odesz̨o i już nie wrócl), pewne przesunięcia znaczeń w pierwszym i drugim wersie drugiej strofy (w oryginale dosł. wspomne, jak w tym roku w maju // praytulatem ciebie w zoo), wreszcie najsilniejsze odstępstwo $\mathrm{w}$ ostatniej strofie, która $\mathrm{w}$ oryginale dosłownie brzmi: ty naprawde $w$ tamtym czasie / w samym centrum (w petnym śnietle) tego śniata / stateś, obserwujac go, cryż nie? ${ }^{35}$. Na ile ważą te straty w obliczu zysków w postaci sprawnie zbudowanego sonetu, to już pozostawiam ocenie czytelników.

Dość powszechne wydaje się przekonanie, że szczytowymi formami rozwoju poezji japońskiej (gdy mowa o układzie metrycznym) był krótki wiersz tanka, a później haiku. Natomiast wiersz współczesny (czyli shi lub gendaishi), jeśli chodzi o formę, zrównuje się zwykle z wierszem wolnym. Starałem się wykazać w niniejszym artykule, jak błędne jest to przekonanie, któremu całkowicie kłam zadaje poezja sylabiczna czy nawet sylabotoniczna (zwłaszcza sonety) Chūyi Nakahary.

\section{Podsumowanie}

Celem artykułu było ukazanie - na podstawie analizy jednego wiersza - na czym polegało nowatorstwo poezji ,japońskiego Rimbauda”, czyli Chūyi Nakahary ${ }^{36}$. Zamierzałem również zwrócić uwagę na trudności, jakie stawia przed tłumaczem poezja Nakahary oraz na to, jak bardzo przekład sonetu Wiosna znów prayjdzie zamieszczony w antologii Wiśnie rožkwitte pośród zimy jest nieadekwatny na poziomie

35 W mojej ocenie jest to jednak odstępstwo w pełni usprawiedliwione. Otóż Nakahara poprzez kolokwialną końcówkę -kke w ostatnim wersie czwartej strofy niejako domyka sytuację liryczną soliloquium, w którym podmiot liryczny zastanawia się, ile syn znaczył dla niego. W zaproponowanym tłumaczeniu akcent został tylko nieznacznie przesunięty w kierunku wyznania, że syn był dla niego całym światem; por. M. Meguro, Nihongo byögen bunkei jiten. Ikita reibun de manabu ei chü kan taiyakutsuki [Słownik wyrażeń i konstrukcji składniowych języka japońskiego. Żywe przykłady, wraz z tłumaczeniem na angielski, chiński i koreański], Tokyo 2008, s. 136.

36 Interesujący pogląd wyraża James Kin-Pong Au, uzasadniając swoiste rozchwianie Nakahary - balansowanie w twórczości między tradycją a modernizmem - wpływem praktyki translatorskiej poety. Wszak Ch. Nakahara był czołowym tłumaczem Rimbauda na japoński; zob. J. Kin-Pong Au, The Influence of Arthur Rimbaud on Dai Wang Shu and Nakahara Chüya's Poetry - The Construction of their Poetic Decadent World, „IAFOR Journal of Literature \& Librarianship” 2017, no. 6 (1), s. 5-25, https://doi.org/10.22492/ijl.6.1.01 (dostęp: 3.01.2021). 
dominanty estetycznej utworu. Natomiast zastosowanie serwisu OJAD, a w szczególności dostępnego tam syntezatora mowy, którego jedną z funkcjonalności jest możliwość sporządzenia wykresu tonalnego dowolnego tekstu japońskiego, przyniosło w mojej ocenie bardzo ciekawe rezultaty. Metodologia ta pozwoliła bowiem wykazać, że poeta podejmował wysiłki mające na celu adaptacje sonetu na grunt japoński, co więcej - wysiłki zwieńczone niewątpliwym sukcesem. Nakaharze udało się przełamać bariery języka japońskiego, którego struktura fonematyczna skutecznie, wydawałoby się, uniemożliwia adaptację wiersza sylabicznego, sylabotonicznego, a zwłaszcza tak finezyjnej formy, jaka jest sonet, i stworzyć dojrzały sonet japoński, czego przykładem z cała pewnościa jest wiersz Mata kon haru (Wiosna znów prayjdzie.

Japoński wiersz sylabiczny i sylabotoniczny zasługuje na odkrycie, na przybliżenie go polskiemu czytelnikowi. Sylabizm czy sylabotonizm to wyznaczniki kompozycyjne bardzo trudne do zaadaptowania do japońszczyzny, dlatego dzieło Chūyi Nakahary i finezja, z jaką realizował tę misję, zasługują na uwagę i podjęcie dalszych badań.

\section{SUMMARY}

\section{CHŪYA NAKAHARA AS THE AUTHOR OF JAPANESE SONNET: TRANSLATION PERSPECTIVES}

This article offers a reflection - against the historical and literary background of the epoch on Chūya Nakahara's work (1907-1937), who was the precursor of the Japanese syllabicaccentual verse (particular of the sonnet). Comparative analysis of his poem Mata kon haru (Spring comes again) and its Polish translation (included in the only Polish anthology of contemporary Japanese poetry entitled Cherries bloomed in winter) aims at shedding light on how difficult was the adaptation of the sonnet to the Japanese language.

The OJAD (Online Japanese Accent Dictionary) service seems to offer a new promise for the research practice, proving that the intonation cadence may be treated similarly as feet in the poetry written in European languages. 